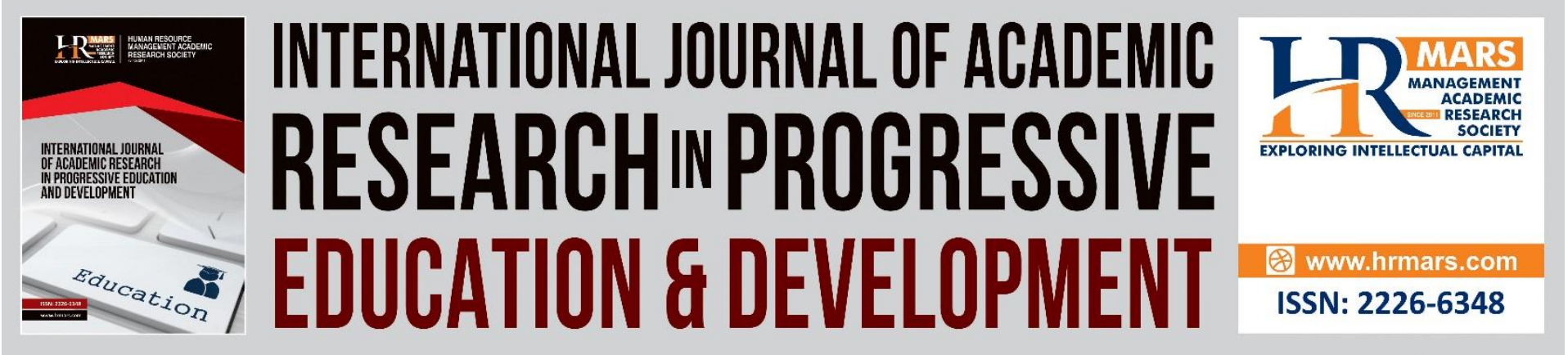

\title{
Fuzzy Delphi Method: The Development of Integrated Play- Based Learning Activity Model to Improve Emotion and Creative Imagination of Preschool Children
}

Abdul Talib Hashim, Nordin Mamat, Azli Ariffin, Abdul Rahim Razalli, Mohd Mahzan Awang, Aqilah Shaidan

To Link this Article: http://dx.doi.org/10.6007/IJARPED/v10-i2/10315 DOI:10.6007/IJARPED/v10-i2/10315

Received: 28 April 2021, Revised: 30 May 2021, Accepted: 17 June 2021

Published Online: 29 June 2021

In-Text Citation: (Hashim et al., 2021)

To Cite this Article: Hashim, A. T., Mamat, N., Ariffin, A., Razalli, A. R., Awang, M. M., \& Shaidan, A. (2021). Fuzzy Delphi Method: The Development of Integrated Play-Based Learning Activity Model to Improve Emotion and Creative Imagination of Preschool Children. International Journal of Academic Research in Progressive Education and Development, 10(2), 1065-1080.

Copyright: (c) 2021 The Author(s)

Published by Human Resource Management Academic Research Society (www.hrmars.com)

This article is published under the Creative Commons Attribution (CC BY 4.0) license. Anyone may reproduce, distribute, translate and create derivative works of this article (for both commercial and non-commercial purposes), subject to full attribution to the original publication and authors. The full terms of this license may be seen at: http://creativecommons.org/licences/by/4.0/legalcode

Vol. 10(2) 2021, Pg. 1065 - 1080

http://hrmars.com/index.php/pages/detail/IJARPED

JOURNAL HOMEPAGE

Full Terms \& Conditions of access and use can be found at http://hrmars.com/index.php/pages/detail/publication-ethics 


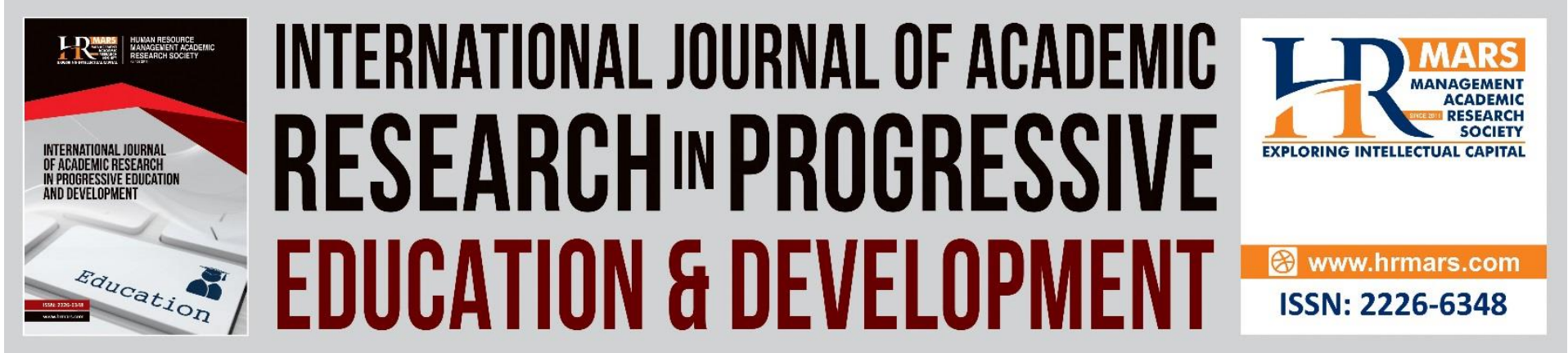

\title{
Fuzzy Delphi Method: The Development of Integrated Play-Based Learning Activity Model to Improve Emotion and Creative Imagination of Preschool Children
}

\author{
Abdul Talib Hashim, Nordin Mamat, Azli Ariffin, Abdul Rahim \\ Razalli \\ Faculty of Human Development, Sultan Idris Education University (UPSI), Tanjong Malim, \\ Malaysia \\ Email: abdul.talib@fpm.upsi.edu.my
}

Mohd Mahzan Awang

Faculty of Education, National University of Malaysia (UKM), Bangi, Malaysia

\section{Aqilah Shaidan}

Faculty of Education and Psychology, Southern University College (KUS), Skudai, Malaysia

\begin{abstract}
This article aims to propose an integrated play-based learning activity model for preschool children. This learning activity model was developed based on the results of case studies conducted through document analysis, interviews and Fuzzy Delphi Method (FDM) on a group of 25 early childhood education experts in order to identify suitable learning through play activities. Meta-analysis was conducted to gather and list down emotion and imaginative (emoginative) game activities garnered from previous studies' findings. The interview method, involved 3 respondents -2 senior preschool teachers, and 1 early childhood education lecturer. The emoginative activities identified from previous meta-analysis method were presented to them and their consent were recorded. The findings from the metaanalysis method highlighted 20 suitable learning through play activity items based on emotion and imagination. The result of the interview shows that the respondents are all in agreement and further suggested the 18 activities to be conducted during teaching and learning process. Meanwhile, the results from FDM highlighted the experts' Agreement Value to be at a rather high range, which is 37.2 to 43.4. The study findings also suggest that learning through play must undergo 3 phases, namely Expose, Expedition and Excite. Such a teaching strategy is meant to improve children's involvement as intrinsic motivation. At the same time, the children's imagination and creativity can be formed more strategically, while simultaneously
\end{abstract}


developing skills required to face the 21st-century challenges.

Keywords Cooperative Learning, Play-based Learning, Motivation, Imagination, Creativity

\section{Introduction}

The essence of national education is to generate creative and innovative individuals and society. This aspiration has been translated through policies and practices directed toward building a creative and innovative society. Citing the 10 Shifts of the Malaysia Higher Education Blueprint (2015-2025), building an eminently imaginative and innovative society will be the catalyst to the achievement of each outlined shift. The ability to imagine is a significant prerequisite to produce and translate creative ideas. According to Richards (2010), imagination is a vital element for an individual's creativity development. This initiative must start from the earliest childhood as imagination reaches its peak level between the ages of 4 to 5 (Susan, 2010; Wood, 2014a).

\section{Emotion and Creative Imagination}

Imagination is a vital part of a person's creativity development (Torrance, 2004; Holzman, 2009; Cheng \& Johnson, 2010). An individual might become a more creative person based on his or her level of emotion and imagination. Creative emotion and imagination are the force of problem-solving and the synthesis of human mind, by recombining past life experience into the creation of a new image and image pattern (Runco \& Jaeger, 2012; Datnow, 2020).

Vygotsky (2004) had extensively discussed theories of the relationship between imagination and creativity. He explained that imagination works as an important motivation involving children's creative activities. With such a manner, the creative activities and behaviour of the children are shaping them to become creative thinkers and future-oriented. However, children still require supports from adults or teachers to reach that point. Vygotsky asserts that children have less imagination than adults. Therefore, the key principle in framing the operation of the imagination is the sensitivity by the teacher, as the closest adult to the children, to identify the existing experience by the student individually Guilford, 1987; Daniels, et al., 2007). This is so because children imagination should be built and developed by leveraging materials which are closely related to the student's actual experience and reality (Bodrova \& Leong, 2007). Vygotsky explained the close association of affective (emotion) and imagination factors as the emotion imagination reality.

Vygotsky also affirms that the nurturing of children's creative imagination must involve emotion that is based on their actual experience and reality (Bodrova \& Leong, 2007; Runco \& Jaeger, 2012). He formulated this argument by presenting four 'laws' on the children's creative imagination and reality linkage in his paperwork entitled Imagination and Creativity in Childhood as follows (Vygotsky, 2004):

Law 1: Creative imagination depends on the experience

Law 2: Experience depends on the imagination

Law 3: All forms of creative imagination include affective (emotion) elements

Law 4: Creative imagination is actualized when a substance is produced

Based on these four laws, there is a close relationship between emotion and creative imagination as well as the importance of imagination to nurture creative behaviour and thinking that is future-oriented. As the experience grows, an individual's creative imagination 
would also become immense (Wood, 2014a).

\section{Teaching for Emotion, Imagination and Creativity Development}

According to Cheng \& Johnson (2010), the success in constructing creative emotion and imagination of the preschoolers' is closely associated with the teacher's notion towards the student's concept of creativity, the student's emotion and the ambience of the classroom when the lesson takes place. However, pressures from various parties and stakeholders, such as parents and the school administration steer the preschool teachers to focus solely on teaching to memorize letters and numbers (Fortson \& Reiff, 1995; Pfeiffer, 2012). This trend has resulted in the decline of imagination and creativity during the early stages of childhood. This situation is worrying as the development of emotion, imagination and creativity of the children begin in their early ages (Roskos \& Christie, 2007; Wood, 2014b; Kay, et al., 2019). The strategy of the preschool teachers that is more inclined in emphasizing such learning content force the children to only stay put and listen. The combination of such teaching strategy by the teacher and the children's learning style restricts the children's opportunity to dream, imagine and play with emotion. As a result, the creative emotion and expression of the children are impeded and stunted (Kavitha \& Manonmani, 2014; Rauschenbach \& Riedel, 2016; Richardson \& Mishra, 2018)

Several previous studies also indicated that the peak levels of children's imagination and creativity are between the ages of four to five years (Bruce, 2011; Lillard, et al., 2013). A study conducted by Torrance (1974) indicates the peak levels of children's creative thinking are in the early years of school, which are from grade one to grade four. Unattractive learning environment and style, however, disrupts the development of the children's creative emotion and imagination. Many researchers have argued that the declination of the children's creative emotion and imagination is the result from their environment and culture, and not a naturallyoccurring process (Torrance, 1974; Bart, et al., 2017).

Children should be exposed to various kinds of interesting experience in the classroom. Class activities, such as to play with emotion and to fantasize, could encourage children to be imaginative and creative. Such learning experience in the preschool classroom through playbased activities could improve their positive behaviour and stimulate creative and critical thinking (Cropley, et al., 2014; Lucas, 2016). If the children not being presented with the opportunity to express their emotion and produce creative ideas during the learning process, their naturally creative thinking and emotion, therefore, will be stunted (Fleer, 2010; Tang \& Werner, 2017).

Based on the above discussion, this study aims to:

a) Identify play activities based on emotion and imagination in order to enhance children's creative

imagination ability, and

b) Propose an integrated play-based learning activity model to be used by preschool teachers.

\section{Methodology}

This study is conducted by using a combination of qualitative and quantitative approaches. The data collection technique, sampling and data analysis process are as follow: 
DEVELOPMENT

Vol. 10, No. 2, 2021, E-ISSN: 2226-6348 @ 2021 HRMARS

\section{Data Collection}

Meta-Analysis

Meta-analysis was conducted to generate a list of play activities based on creative emotion and imagination suitable to be applied for the enhancement of preschool children's creative imagination. The term meta-analysis was introduced by Gene Glass (1976) to represent the findings of particular analyzed research bound to be integrated with findings from other studies. Meta-analysis is an assessment of a document furnished by the researcher, garnered from the findings of various studies or sources that address the research question (Hunter \& Schmidt, 2004; Borenstein, 2009)

\section{Interview}

The expert interview was conducted in two sessions. In the first session, 3 experts were involved in the individual interview manner. This session aims to gather the experts' views and additional information on the list of play-based activities as well as to acquire the validity of the meta-analysis content. The second session was focus group interviews. The purpose of focus group interviews is to acquire the experts' level of agreement on the play-based activities and to discuss the suggestions of suitable play-based learning activities based on experts' experience. Interview is defined as a two-way conversation to collect research information (Creswell, 2018). In both interview sessions, either individually or in the focus group, the researcher adopted the open-ended interview type (Kaufmann \& Gupta, 1988).

\section{Questionnaire}

In this research, a set of questionnaires was distributed to the experts by using the Fuzzy Delphi Method (FDM). The instruments in FDM is a set of questionnaires employed to collect data from the discussion with the experts according to the designated criteria (Kaufmann \& Gupta, 1988). The instrument of questionnaires was constructed based on the findings from the meta-analysis and individual interviews conducted. The questionnaires adopted the seven-point Likert scale.

\section{Sampling and Data Analysis}

The sampling process and data analysis were conducted in three phases as follow:

Phase 1

The research sample for the meta-analysis in this study refers to the number of references adopted during the literature review of previous studies (Borenstein, 2009). Essentially, meta-analysis does not have a fixed number of samples. However, the researcher was guided by 20 references and previous studies from various sources, such as journals, books and articles, as suggested by Koricheva, Gurevitch, and Mengersen (2013). They state that the appropriate range of literature review is from 20 to 30 reference materials. Among the keywords charted to locate the materials and articles pertaining to the study was "play activities", "exciting learning", "imagination skill", "emotional development", "imagination and creativity", "creative elements", "primary school education", "children emotional development", "creative activities", and "creative learning activities".

The meta-analysis method in the first phase of this study was carried out systematically based on the findings from the selected articles. The shortlisted items were then selected to suit the research questions' needs. 


\section{Phase 2}

Samples in the interview sessions are referred to as the experts within the field of research. An expert can be defined as an individual with vast experience and skills in a particular field (Denzin \& Lincoln, 2017). According to Creswell (2018) an individual can be categorized as an expert if they have the experience in a certain field at least for 5 to 10 years. Sample selection for the individual interviews is based on purposive sampling, which only involved three experts predetermined by the researcher - all are preschool teachers. Respondent $A$ has been in service for 14 years, Respondent B for 9 years, while Respondent C for 8 years. During those interviews, the researcher had asked the experts whether there are items to be added, removed, or the experts agree with the items.

The data analysis method for these interviews involved the process of data organization and reduction, theme construction, data assessment and also making verification with a conclusion (Creswell, 2018).

\section{Phase 3}

In this study, the Fuzzy Delphi method was employed to identify the experts' level of agreement on the elements and suggestions of teaching strategy for play-based learning activities (Kaufmann \& Gupta, 1988). These elements were acquired from the previous processes of meta-analysis and interviews. Subsequently, they were reconstructed into a) a set of checklist, and b) suggestions of teaching strategy model to be discussed by the experts during their workshop meeting. A total of 25 experts were involved in the session.

The process and procedure included in analyzing the data from Phase 2 and phase 3 began with 1) Expert Selection, b) Determining the Linguistic Scale Based on the Fuzzy Triangle, c) Calculating the Averages of Experts' Responses, d) Identifying the Threshold Value, e) Fuzzy Assessment Aggregate, f) Defuzzification Process, g) Ranking (tems, until h) discussion on the suggestions of teaching models (Ishikawa, et al., 1993; Ridhuan, et al., 2019)

\section{Results and Discussion}

\section{The Elements of Play Activities based on Children's Emotion and Imagination}

This section will discuss the first issue of this research; what are the suitable elements of play activities based on children's emotion and imagination to enhance children's creative imagination ability.

The list of play activities in Table 1 below is the result from the conducted meta-analysis, which incorporated the combination of several previous studies along with references from various sources such as journals, books and articles. 
INTERNATIONAL JOURNAL OF ACADEMIC RESEARCH IN PROGRESSIVE EDUCATION AND DEVELOPMENT

Vol. 10, No. 2, 2021, E-ISSN: 2226-6348 @ 2021 HRMARS

Table 1. List of play-based activities generated from the meta-analysis

\begin{tabular}{|c|c|c|c|}
\hline No. & $\begin{array}{c}\text { Elements of Play Activities Based } \\
\text { on Children's Emotion and } \\
\text { Imagination }\end{array}$ & (f) & $\begin{array}{l}\text { Source (Year) } \\
\qquad(n=20)\end{array}$ \\
\hline 1. & Blocks or LEGO & 1 & $\begin{array}{c}\text { Gorev, P.M., Telegina, N. V., Karavanova, } \\
\text { L. Z., \& Feshina, S.S. (2018). }\end{array}$ \\
\hline 2. & Puppet & 2 & $\begin{array}{l}\text { Luen, L. C. (2011). } \\
\text { Gilliland, C. (2017). }\end{array}$ \\
\hline 3. & Extempore & 1 & Deepa, S. (2012). \\
\hline 4. & Jigsaw puzzle & 1 & Read, C. (2007). \\
\hline 5. & Sketch or draw games & 2 & $\begin{array}{c}\text { Pelowski, M. (2017). } \\
\text { Walsh, G., McMillan, D., \& McGuinness, } \\
\text { C. (2017). }\end{array}$ \\
\hline 6. & Connecting-story games & 1 & Read, C. (2007). \\
\hline 7. & Treasure hunt & 1 & $\begin{array}{l}\text { Walsh, G., McMillan, D., \& McGuinness, } \\
\text { C. (2017). }\end{array}$ \\
\hline 8. & Sand play & 1 & Kiewra, C., \& Veselack, E. (2016). \\
\hline 9. & Storytelling & 3 & $\begin{array}{l}\text { Hedges, H. (2014). } \\
\text { Saracho, O. (2012). } \\
\text { Mahzan, A. (2012). }\end{array}$ \\
\hline 10. & Create a musical instrument & 1 & Borsay, K. D., \& Foss, F. (2016). \\
\hline 11. & Cooking & 1 & Read, C. (2007). \\
\hline 12. & Tangram & 2 & $\begin{array}{l}\text { Siew, N. M., \& Chong, C. L. (2014). } \\
\text { Gorev, P.M., Telegina, N. V., Karavanova, } \\
\text { L. Z., \& Feshina, S.S. (2018). }\end{array}$ \\
\hline 13. & Singing & 3 & $\begin{array}{c}\text { Walsh, G., McMillan, D., \& McGuinness, } \\
\text { C. (2017). } \\
\text { Bower, V., \& Barrett, S. (2014). } \\
\text { Mahzan, A. (2012). }\end{array}$ \\
\hline 14. & Create a mask & 1 & Ray, D. (2019). \\
\hline 15. & Experiment & 2 & $\begin{array}{l}\text { Craft, A. (2008). } \\
\text { Trnova, E. (2015). }\end{array}$ \\
\hline 16. & Visualisation reading & 1 & Read, C. (2007). \\
\hline 17. & Collage & 1 & Pelowski, M. (2017). \\
\hline 18. & Dancing & 1 & Cheun, H. P. (2010). \\
\hline 19. & Play dough & 1 & Duncan, P. A. (2015). \\
\hline 20. & Role-play & 2 & $\begin{array}{l}\text { Mahzan, A. (2012). } \\
\text { Dohearty, A., \& McCulash, J. (2017). }\end{array}$ \\
\hline
\end{tabular}

All of these sources in the figure above had conducted their research on play-based activities among children and appropriate to the levels of age concerning this research. This shows that play-based activities are still relevant to enhance children's creative imagination, regardless of the possibility that the elements stated are the play-based activities that have never been practiced by the experts in their teaching. 
INTERNATIONAL JOURNAL OF ACADEMIC RESEARCH IN PROGRESSIVE EDUCATION AND

DEVELOPMENT

Vol. 10, No. 2, 2021, E-ISSN: 2226-6348 @ 2021 HRMARS

Next, the results from the analysis of the first interview session with experts are shown in Table 2 below:

Table 2. Examples of play-based activities gathered from the interview

\begin{tabular}{|c|c|c|}
\hline $\begin{array}{l}\text { Respondent } \\
\text { (R) }\end{array}$ & The Importance of Play Activities & $\begin{array}{c}\text { Suggestions for Activities to be } \\
\text { Conducted }\end{array}$ \\
\hline A & $\begin{array}{l}\text { Students are in their own sphere. } \\
\text { Creative thinking can be observed } \\
\text { through imagination. }\end{array}$ & $\begin{array}{l}\text { “...if the teacher gives them a } \\
\text { colour kit with drawing paper and } \\
\text { asks to create anything to their } \\
\text { imagination..." } \\
\text { (Drawing) } \\
\text { “...dance can also help } \\
\text { imagination..." } \\
\text { (Dancing) } \\
\text { "...the same goes with acting } \\
\text { where normally specific characters } \\
\text { will be created according to the } \\
\text { story plot..." } \\
\text { (Drama) }\end{array}$ \\
\hline B & $\begin{array}{l}\text { Reinforces creative thinking } \\
\text { Understanding something more easily } \\
\text { Creativity can be enhanced because } \\
\text { the student becomes more excited } \\
\text { and get to learn in a relaxed condition }\end{array}$ & $\begin{array}{c}\text { “...I prepared pieces of photos that } \\
\text { can be narrated according to their } \\
\text { creativity..." } \\
\text { (Picture matching) } \\
\text { "...teachers could conduct visual } \\
\text { reading activities..." } \\
\text { (Visualisation reading) }\end{array}$ \\
\hline C & $\begin{array}{l}\text { Creative imagination can be inculcated } \\
\text { as students feel more fun in learning }\end{array}$ & $\begin{array}{l}\text { "...usually, Science is related to } \\
\text { discovery activities..." } \\
\text { (Experiment) } \\
\text { "...I am not sure about the name, } \\
\text { but it is kind of a block game..." } \\
\text { "...it is more to expose students } \\
\text { with geometries..." } \\
\text { (Tangram) }\end{array}$ \\
\hline
\end{tabular}

The level of Experts' Agreement on play-based Activities

To identify the level of experts' agreement on play-based activities, Fuzzy Delphi Method had been chosen to evaluate activity items acquired from the meta-analysis technique and interviews (Ishikawa, et al., 1993; Ridhuan, et al., 2019). Those items are framed into a set of checklist and discussed by the experts in the experts' workshop meeting. There were 25 experts in total involved during the session. 
INTERNATIONAL JOURNAL OF ACADEMIC RESEARCH IN PROGRESSIVE EDUCATION AND DEVELOPMENT

Vol. 10, No. 2, 2021, E-ISSN: 2226-6348 @ 2021 HRMARS

Table 3. The defuzzification value of play-based activity items

\begin{tabular}{|c|c|c|c|c|c|c|}
\hline \multirow{2}{*}{\multicolumn{2}{|c|}{ No. Item }} & \multicolumn{2}{|c|}{ Triangular Fuzzy Number } & \multicolumn{3}{|c|}{ Defuzzification process } \\
\hline & & $\begin{array}{c}\text { Threshold } \\
\text { Value } \\
\text { (d) }\end{array}$ & $\begin{array}{c}\text { Overall } \\
\text { Group } \\
\text { Consensus } \\
\\
(\%) \\
\end{array}$ & $\begin{array}{l}\text { Fuzzy } \\
\text { Score } \\
\text { (A) }\end{array}$ & \multirow{2}{*}{$\begin{array}{c}\begin{array}{c}\text { Defuzzificati } \\
\text { on } \\
\text { value }\end{array} \\
\left(X^{*}\right) \\
43.20\end{array}$} & \multirow{2}{*}{$\begin{array}{c}\text { Experts' } \\
\text { Agreement } \\
\text { with the } \\
\text { item } \\
\text { Agree }\end{array}$} \\
\hline 1 & $\begin{array}{l}\text { Arranging } \\
\text { Blocks or } \\
\text { LEGO }\end{array}$ & 0.108 & 84.0 & 0.89 & & \\
\hline 2 & Puppet & 0.097 & 88.0 & 0.86 & 42.45 & Agree \\
\hline 3 & $\begin{array}{l}\text { Extempore } \\
\text { Game }\end{array}$ & 0.146 & 70.0 & 0.45 & 22.65 & $\begin{array}{l}\text { Slightly } \\
\text { Disagree }\end{array}$ \\
\hline 4 & $\begin{array}{c}\text { Sketching or } \\
\text { Drawing }\end{array}$ & 0.097 & 100.0 & 0.88 & 42.70 & Agree \\
\hline 5 & $\begin{array}{l}\text { Connecting- } \\
\text { Stories Game }\end{array}$ & 0.112 & 88.0 & 0.87 & 42.33 & Agree \\
\hline 6 & Treasure Hunt & 0.116 & 76.0 & 0.85 & 42.10 & Agree \\
\hline 7 & Water play & 0.120 & 84.0 & 0.42 & 22.35 & $\begin{array}{l}\text { Slightly } \\
\text { Disagree }\end{array}$ \\
\hline 8 & Sand Play & 0.090 & 80.0 & 0.86 & 41.00 & Agree \\
\hline 9 & Story telling & 0.139 & 96.0 & 0.43 & 21.05 & $\begin{array}{c}\text { Slightly } \\
\text { Disagree }\end{array}$ \\
\hline 10 & $\begin{array}{c}\text { Make Musical } \\
\text { Instruments }\end{array}$ & 0.146 & 76.0 & 0.35 & 16.25 & $\begin{array}{c}\text { Slightly } \\
\text { Disagree }\end{array}$ \\
\hline 11 & $\begin{array}{l}\text { Cooking } \\
\text { Activities }\end{array}$ & 0.132 & 84.0 & 0.23 & 12.5 & Disagree \\
\hline 12 & $\begin{array}{l}\text { Change Lyrics } \\
\text { to a Kids Song }\end{array}$ & 0.151 & 68.0 & 0.28 & 14.35 & Disagree \\
\hline 13 & $\begin{array}{c}\text { Creating } \\
\text { Animal Masks }\end{array}$ & 0.146 & 76.0 & 0.82 & 38.90 & $\begin{array}{c}\text { Moderately } \\
\text { Agree }\end{array}$ \\
\hline 14 & $\begin{array}{c}\text { Telephone } \\
\text { and Turn- } \\
\text { taking } \\
\end{array}$ & 0.132 & 100.0 & 0.80 & 39.70 & $\begin{array}{c}\text { Moderately } \\
\text { Agree }\end{array}$ \\
\hline 15 & Experiment & 0.160 & 68.0 & 0.44 & 22.42 & $\begin{array}{c}\text { Slightly } \\
\text { Disagree }\end{array}$ \\
\hline 16 & Role-play & 0.105 & 84.0 & 0.86 & 41.60 & $\begin{array}{c}\text { Moderately } \\
\text { Agree }\end{array}$ \\
\hline 17 & Drama & 0.105 & 76.0 & 0.86 & 40.90 & $\begin{array}{c}\text { Moderately } \\
\text { Agree }\end{array}$ \\
\hline 18 & Collage & 0.144 & 100.0 & 0.80 & 39.85 & $\begin{array}{c}\text { Moderately } \\
\text { Agree }\end{array}$ \\
\hline 19 & Shadow Play & 0.140 & 80.0 & 0.80 & 39.35 & $\begin{array}{c}\text { Moderately } \\
\text { Agree }\end{array}$ \\
\hline 20 & Guessing & 0.148 & 100.0 & 0.48 & 23.75 & Slightly \\
\hline
\end{tabular}


INTERNATIONAL JOURNAL OF ACADEMIC RESEARCH IN PROGRESSIVE EDUCATION AND DEVELOPMENT

Vol. 10, No. 2, 2021, E-ISSN: 2226-6348 @ 2021 HRMARS

\begin{tabular}{|c|c|c|c|c|c|c|}
\hline & Game & & & & & Disagree \\
\hline 21 & Dancing & 0.120 & 92.0 & 0.75 & 37.20 & $\begin{array}{c}\text { Moderately } \\
\text { Agree }\end{array}$ \\
\hline 22 & Modelling & 0.130 & 84.0 & 0.76 & 38.75 & $\begin{array}{c}\text { Moderately } \\
\text { Agree }\end{array}$ \\
\hline 23 & Hopscotch & 0.135 & 100.0 & 0.78 & 39.10 & $\begin{array}{c}\text { Moderately } \\
\text { Agree }\end{array}$ \\
\hline 24 & Clay & 0.097 & 84.0 & 0.86 & 41.35 & $\begin{array}{c}\text { Moderately } \\
\text { Agree }\end{array}$ \\
\hline 25 & $\begin{array}{l}\text { Rhythmic } \\
\text { Creative } \\
\text { Movement }\end{array}$ & 0.067 & 96.0 & 0.88 & 43.40 & Agree \\
\hline 26 & Ball of music & 0.152 & 100.0 & 0.80 & 39.50 & $\begin{array}{c}\text { Moderately } \\
\text { Agree }\end{array}$ \\
\hline
\end{tabular}

Table 3 above exhibits the defuzzification value for the play-based activity items which are retained after the percentage calculation process in the construction of this element. Rejected items are no. 3, 7, 9, 10,11, 12, 15 and 20. The calculation process of defuzzification value is to identify the level of experts' agreement concerning the agreed items during the discussion process. The acceptable range of defuzzification value to attain the level of experts' agreement is from 33.6 to 46.8 (Ishikawa, et al., 1993; Ridhuan, et al., 2019).

\section{Integrated Teaching Strategies for Play-based Activities}

Based on the above findings, the discussion session by the group of experts also refined and proposed teaching strategies in implementing appropriate play-based activities to enhance preschool children's emotion and imagination. The discussion was focused on adapting their practical knowledge on coordinating play-based activities with the contextual knowledge of the students, such as their backgrounds, capabilities and tendencies.

A number of themes and subthemes quoted by the experts' group indicate their teaching strategy by play-based activities as routine. The analysis result from the expert group's discussion on inculcating play-based activities to enhance emotion and imagination can be summarized into the following figure: 


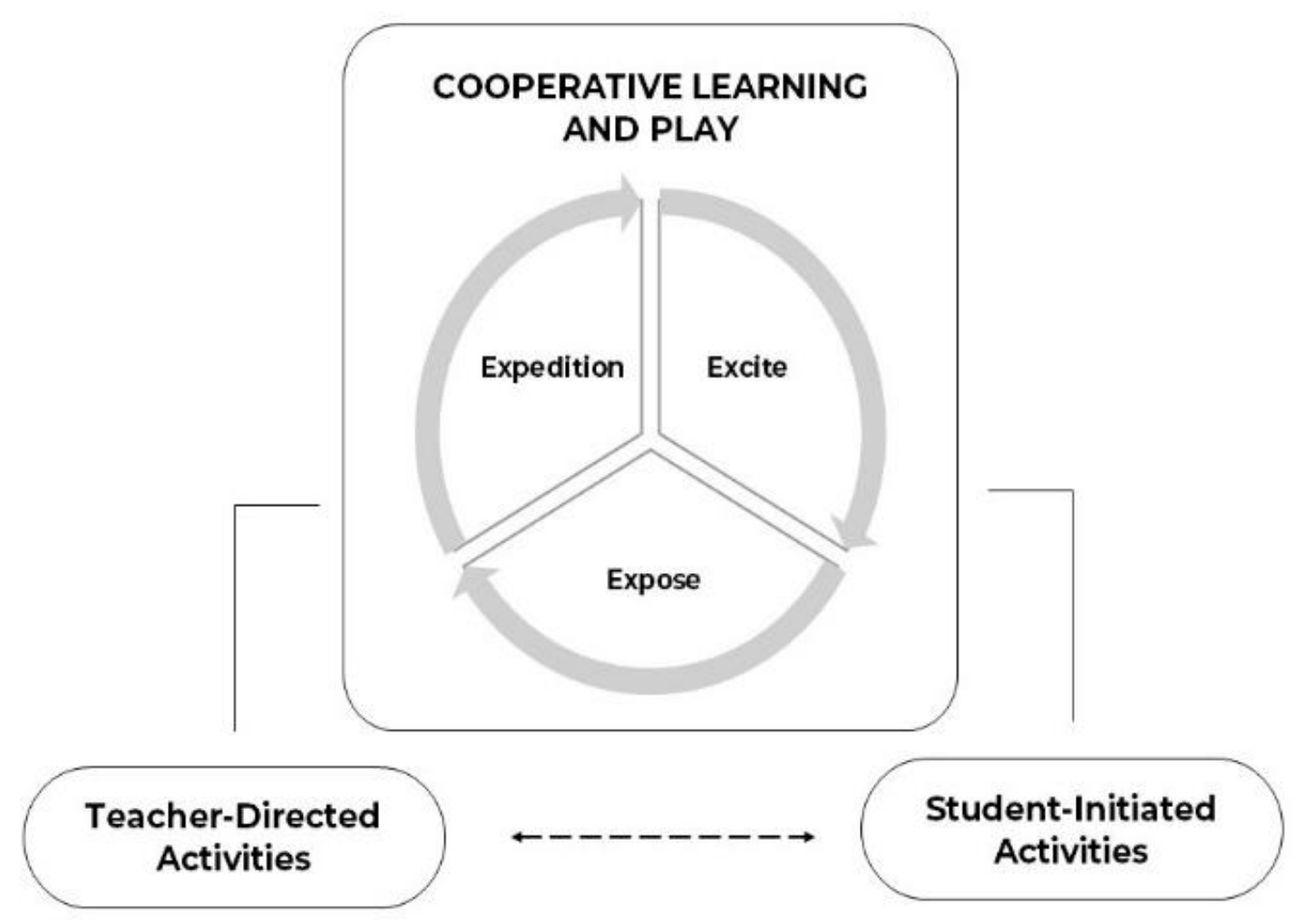

Figure 1. A model of integrated teaching strategies for play-based activities

This model of teaching strategies was developed by considering opinions from experts of their routine activities along with Wood's integrated approach (Wood, 2010), which is the teaching by play activities travels through a two-way continuum line, between teacherdirected activities and student-initiated activities. The teacher-directed activities comprise every lesson that was predetermined by the teacher, aligned with the needs of the curriculum or syllabus. It functions as a task for students as the learning outcomes have been set and they have very few options on the content and manner of the lesson takes place.

It contrasts with the other end of the continuum, where despite the children is being assigned, the principle and orientation of play, however, exist. Children get to express responses appropriate to the teacher's teaching activity, along with personalizing the play activity to suit their style of learning and passion (Roskos \& Christie, 2007; Wood, 2014a). The activity becomes student-oriented because the character of learning morphs into intrinsic motivation, as well as the controls of emotion, imagination and autonomy, which occurs upon the children. That is to say, the assignment by the teacher had become a desire and motivation to play by the children. Wood explained that the desire to participate in play activities does not require overly structured curriculum planning and organization. It will succumb the student's interest, imagination and creativity. With regards to that, cooperative learning is made the keystone for developing the integrated model.

\section{Cooperative Play and Learning}

This conducted research found that all of the participating experts had applied group play activities. The group play activities had been perceived as fitting to the characteristics of 
cooperative learning, as most studies conducted on 3-6 years old children (Craft, et al., 2012; Ackay, 2016; Saracho, et al., 2019), which are sharing toward developing mutual knowledge, solving conflicts at the cognitive level, establishing mutual condition or platform, and achieving mutual vision or motivation in learning. The participating experts had also agreed on the difficulties in evaluating the play activities as it demands a high level of collaboration among the children. In addition, all experts agreed play activities entail the students to apply higher-order thinking skills, such as questioning, negotiating, reasoning and arguing.

The group play activities proposed by the experts could improve the children's social and interpersonal skills, open up the space to communicate and overcome differing opinions among children. This technique is also perceived as fitting to Vygotsky's view on the Zone of Proximal Development (ZPD), where children are capable of reaching potential growth level that could be developed through collaboration with their more capable peers (Holzman, 2009; Richardson \& Mishra, 2018; Saracho, et al., 2019). As it appears that the play-based learning activities carried out freely by the children would not help the learning process, the experts agreed on some systematic and structured conducts or models to coordinate play activities based on emotion and imagination (Bodrova, \& Leong, 2007, Wood, 2014b). This suggestion by experts comprises of three main phases (see Figure 1). Each phase has its rationality and must be undergone to ensure every child enrol in the system attain every required objective of the play-based learning activities, as the following explanations:

\section{Expose}

The element of expose involves students' discussion on the information they need to gather to carry out the play-based learning activity and the tasks that have been assigned to individuals or groups. The teacher must play the role of a facilitator by briefing the concept of play and its relation with the topic or content of learning. To accommodate students in the understanding process, the teacher might as well showcases the expected result model from the play activity. For a more effective cooperative play and learning approach, children must be grouped into several partners or small groups according to the needs and goals of the play. Each partner or small group are allocated time to discuss each member's task and role during the activity is taking place. At this stage, groups are given the autonomy to decide the learning content, how and where the lesson takes place. Each group member must actively raise questions or being vocal in the dialogue to affirm their understanding of the task and role. Once children started to ask the question on the rules and implementation process of the play-based learning activity, the teacher must encourage them to correlate between the learning outcomes of the day with the real world.

\section{Expedition}

The next ' $E$ ' element in this technique is expedition. The nature of the expedition requires students to play based on the assigned task and role. The purpose of the expedition during this play is not only to solve the given assignment but also giving the children experience to transform themselves toward a seemingly actual situation. Problem-solving skill and applying information are accentuated at this stage. The student's openness to frame themselves pertinent to the role and rules of play could shape up their positive thinking toward something. This activity also directly trains them to conform in a multicultural situation. It is at this stage that personal learning occurs and the teacher may grant children the freedom to choose a task or role based on their past learning experiences and interests. When children 
decide to participate in a certain play-based learning activity, they gain a learning experience regarding the freedom of making decisions. Through the expedition in a play-based learning activity, they can also begin to see the linkage between their decision and the imaginary role they took with the consequences or effects from their choice or role.

\section{Excite}

The last ' $E$ ' element in this teaching technique refers to the emotions of happiness and excitement by the children in participating the play-based learning activity. The excitement to play among the children occurs due to their natural desire to understand real life. Such intrinsic motivation enables children to control their feelings and desires to stay playing. At this point, to take care of their peers' feelings is more important than their own to prevent the ball from stop rolling. These emotional and self-control skills by the children would benefit them in the future. Besides that, children would not be aware of the time and their environment during the play. The risk-free environment grants children the opportunity to experiment and discover new ideas. For this course, failures and mistakes are allowed. However, it is the duty of the teacher to constantly remind students on the role of imagination or fantasy during play with the real world. With regards to that, it is at this point that the experts aim to nurture children's assessment skill and critical behaviour upon every situation during the play-based learning activity. Other than that, it also promotes the development of flexibility in their thinking and decision making. There is a fine line between playing as a role in learning, with playfulness as an attitude. Playful attitude furnishes students opportunities to discover new experiences encompassing the proliferation of thoughts to imagine and the ability to control emotion, besides exploring various possibilities.

\section{Conclusion}

The teaching strategy of play-based learning activities as practiced and suggested by experts and explained through the integrated model above is expected to enhance children's creative emotion and imagination skills. Several play-based activities were also identified for this age group, all of those based on the principle of play activities agreed by the experts, they are a) to create a learning environment that could promote intrinsic motivation upon the children on what and how do they learn, and b) to prepare a risk-free environment for the children to experiment and trying new ideas. This context of learning is fitting to the proposal by Vygotsky (2004) that "every inventor, even a genius, is also a product of his time and his environment... Creation is a historical, cumulative process where every succeeding manifestation was determined by the preceding one" (p. 30). Craft (2003), on the other hand, affirms that "play is necessary to creativity, not all play is creative" (p. 150). With regards to that, teachers are also bound to consider a suitable teaching strategy when deciding to apply play activity in teaching. At the end of the day, teachers have to come up how the play activity could stimulate children's emotion and enhance their creative imagination.

\section{Acknowledgements}

This paper is based on the reseach project entitled 'Pembinaan model aktiviti pembelajaran berasaskan emosi dan imaginasi (Emoginatif) untuk peningkatan imaginasi-kreatif kanakkanak'. The authors would like to extend their gratitude to Sultan Idris Education University (UPSI) for the University Research Grants for Education (GPUBP Code: 2018-0233-107-01) that helped fund the research. 
DEVELOPMENT

Vol. 10, No. 2, 2021, E-ISSN: 2226-6348 ㄷ 2021 HRMARS

\section{Corresponding Author}

Abdul Talib Hashim

Department of Educational Studies, Faculty of Human Development, Sultan Idris Education University (UPSI), 35900 Tanjong Malim, Perak, MALAYSIA

Email: abdul.talib@fpm.upsi.edu.my

\section{References}

Akcay, N. O. (2016). Implementation of Cooperative Learning Model in Preschool, Journal of Education and Learning, vol. 5, no. 3, pp. 83-93., DOI:10.5539/jel.v5n3p83

Bart, W. M., Hokanson, B., \& Can, I. (2017). An investigation of the factor structure of the Torrance Tests of Creative Thinking, Educational Sciences: Theory and Practice, 17 (2), pp. 515-528.

Bodrova, E., \& Leong, D. J. (2007). Play and early literacy: A Vygotskian approach, in K. A. Roskos, J. F. Christie, Play and literacy in early childhood: Research from multiple perspectives, London: Routledge, pp. 185-200.

Borenstein, M. (2009). Introduction to Meta-Analysis, Chichester: John Wiley \& Sons.

Bruce, T. (2011). Cultivating creativity: For babies, toddlers and young children, (2nd Ed.), London: Hodder Education.

Cheng, M. F., \& Johnson, J. E. (2010). Research on children's play: Analysis of developmental and early education journals from 2005 to 2007, Early Childhood Education Journal, 37, pp. 249-59.

Craft, A. (2003). Creative thinking in the early years of education, Early Years Journal of International Research \& Development, 23, pp. 143-154.

Craft, A., McConnon, L., \& Matthews, A. (2012). Child-initiated play and professional creativity: Enabling four-year-olds' possibility thinking, Thinking Skills and Creativity, 7 (1), pp. 48-61.

Creswell, J. W. (2018). Research Design: Qualitative, Quantitative, and Mixed Method Approaches, (5th Ed.). Thousand Oaks, CA: SAGE.

Cropley, D., Kaufman, J. C., Murphy, M., \& Moran, S. (2014). Summary creativity and ethicsTwo golden eggs, in S. Moran, D. Cropley, J. C. Kaufman, The Ethics of Creativity, Basingstoke: Palgrave Macmillan, pp. 299-307.

Daniels, H., Cole, M., \& Wertsch, J. V. (2007). The Cambridge companion to Vygotsky, New York: Cambridge University Press.

Datnow, A. (2020). The role of teachers in educational reform: A 20-year perspective, Journal of Educational Change, 21(3), pp. 431-441.

Denzin, N. K., \& Lincoln, Y. S. (2017). The SAGE Handbook of Qualitative Research, London: SAGE.

Fleer, M. (2010). Early learning and development: Cultural-historical concepts in play, Cambridge: Cambridge University Press.

Fortson, L. R., \& Reiff, J. C. (1995). Early childhood curriculum: Open structures for integrative learning, Boston, MA: Allyn and Bacon.

Glass, G. V. (1976). Primary, secondary, and meta-analysis of research, Educational Researcher, 5, pp. 3-8.

Guilford, J. P. (1987). Creativity research: Past, present and future, in S. G. Isaksen, Frontiers of creativity research: Beyond the basics, Buffalo, NY: Bearly Limited, pp. 33-65. 
Holzman, L. (2009). Vygotsky at work and play, London: Routledge.

Hunter, J. E., \& Schmidt, F. L. (2004). Methods of Meta-analysis: Correcting Error and Bias in Research Findings, Thousand Oaks: CA, SAGE.

Ishikawa, A., Amagasa, M., Shiga, T., Tomizawa, G., Tatsuta, R., \& Mieno, H. (1993). The maxmin Delphi method and fuzzy Delphi method via fuzzy integration, Fuzzy Sets System, 55, pp. 241-253., DOI: 10.1016/0165-0114(93)90251-C

Kaufmann, A., \& Gupta, M. M. (1988). Fuzzy Mathematical Models in Engineering and Management Science, Amsterdam: North-Holland.

Kavitha, V., \& Manonmani, G. (2014). Fostering creativity, International Journal of Interdisciplinary Research. ISSN, pp. 2348-6775.

Kay, L., Wood, E., Nuttall, J., \& Henderson, L. (2019). Problematizing policies for workforce reform in early childhood education: A rhetorical analysis of England's early year's teacher status, Journal of Education Policy, A head of print, 1-17, DOI:10.1080/02680939.2019.1637546

Koricheva, K., Gurevitch, J., \& Mengersen, K. (2013). Handbook of meta-analysis in ecology and evolution, Princeton: Princeton University Press.

Lillard, A. S., Lerner, M. D., Hopkins, E. J., Dore, R. A., Smith, E. D., Palmquist, C. M. (2013). The impact of pretend play on children's development: A review of the evidence, Psychological Bulletin, 139 (1), pp. 1-34.

Lucas, B. (2016). A Five-Dimensional Model of Creativity and its assessment in schools, Applied Measurement in Education, 29 (4), pp. 278-290.

Pfeiffer, S. I. (2012). Serving the gifted: Evidence-based clinical and psycho-educational practice, New York: Routledge.

Rauschenbach, T., \& Riedel, B. (2016). Germany's ECEC workforce: A difficult path to professionalization, Early Child Development and Care, 86 (1), pp. 61-77.

Richards, R. (2010). Everyday creativity: Process and way of life-four key issues, in J. C. Kaufman, R. J. Sternberg, The Cambridge Handbook of Creativity, New York: Cambridge University Press, 2010, pp. 189-215.

Richardson, C., \& Mishra, P. (2018). Learning environments that support student creativity: Developing the SCALE, Thinking Skills and Creativity, 27, pp. 45-54. DOI: 10.1016/j.tsc.2017.11.004

Ridhuan, M. J., Saedah, S., Zaharah, H., Nurul, R. M. N., \& Arifin, A. S. (2019). Pengenalan Asas Kaedah Fuzzy Delphi dalam Penyelidikan Reka Bentuk Pembangunan, Selangor: Minda Intelek Agency.

Roskos, K. A., \& Christie, J. F. (2007) Play and literacy in early childhood: Research from multiple perspectives, $\left(2^{\text {nd }} \mathrm{Ed}\right)$, London: Routledge.

Runco, M. A., \& Jaeger, J. G. (2012). The standard definition of creativity, Creativity Research Journal, 24, pp. 92-96. DOI:10.1080/10400419.2012.650092

Saracho, N. O., \& Spodek, B. (2019). Handbook of Research on the Education of Young Children, $\left(4^{\text {th }} \mathrm{Ed}\right)$, London: Routledge.

Susan, W. (2010). Understanding Creativity in Early Childhood, London: SAGE.

Tang, M., \& Werner, C. H. (2017). An interdisciplinary and intercultural approach to creativity and innovation: Evaluation of the EMCI ERASMUS intensive program, Thinking Skills and Creativity, 24, pp. 268-278.

Torrance, E. P. (1974). The Torrance tests of creative thinking: Norms-technical manual, 
Princeton, NJ: Personnel Press.

Torrance, E. P. (2004). Great expectations: Creative achievements of the sociometric stars in a 30-year study, Journal of Secondary Gifted Education, 1, pp. 5-13.

Vygotsky, L. S. (2004). Imagination and creativity in childhood, Journal of Russian and East European Psychology, 42, pp. 7-97. (Original work published 1930).

Wood, E. (2010). Developing integrated pedagogical approaches to play and learning, in P. Broadhead, J. Howard, E. Wood, Play and Learning in the Early Years: From Research to Practice, London: SAGE, pp. 9-26.

Wood, E. (2014a). Free choice and free play in early childhood education: Troubling the discourse, International Journal of Early Years Education, 22(1), pp. 4-18.

Wood, E. (2014b). The play-pedagogy interface in contemporary debates, in L. Brooker, M. Blaise, S. Edwards, The SAGE Handbook of Play and Learning in Early Childhood, London: SAGE, pp.145-156. 